\title{
Seasonal abundance of some sap-sucking pests on Cape gooseberry, Physalis peruviana $\mathbf{L}$.
}

\author{
Afsah, A. F. E. \\ Plant Protection Research Institute, 7 Nadi El-Said Street, Dokki, Giza, Egypt
}

\begin{abstract}
The effect of some weather factors and plant age after transplantation on population of some sapsucking pests on cape gooseberry plants were studied during two successive seasons of 2012 and 2013 at Qaha district, Qalubia Governorate. The cotton whitefly, Bemisia tabaci (Genn.) recorded 6 and 5 peaks at both egg and nymphal stages during two seasons, respectively. The correlation between plant age after transplantation, maximum\& minimum temperature and mean numbers of $B$. tabaci eggs were negative and highly significant effect, but relative humidity ( $\mathrm{RH} \%$ ) recorded negatively significant and wind speed had positive and highly significant effect in first season. In the second season, plant age after transplantation had negative and significant effect, but Max.\& Min. Tempe. had negative and highly significant, while Max.\& Min. RH\% recorded negative and significant and wind speed showed positive and insignificant . B. tabaci nymph had negative and non significantly correlation with all the tested factors in both seasons, except of wind speed had positive non significant in the first season and positive significant in the second season. B. tabaci pupae had 6 and 3 peaks at the two seasons respectively, and all the tested factors had insignificant effect.

The cotton thrips, Thrips tabaci lind. nymphs recorded 4 and 6 peaks in the first and second seasons, respectively, all the tested factors recorded negative and highly significant correlation except of Max. RH \% was non significant, Min. RH \% was significant and wind speed was positive in the first season. In the second season all the tested factors recorded negative and significant correlation except of Max. and Min. RH\% had insignificant and wind speed recorded positive and non significant. Thrips adult recorded three and four peaks in the two seasons , respectively. Statistical analysis in the first season showed that the effect of the tested factors on the mean numbers of adult stage had approximately the same trend with thrips nymphs. But in the second season, plant age after transplanting, Max. \& Min. temperature and wind speed had negatively correlation and insignificant effect except of Max. Temperature had significant effect. While Max. \& Min. relative humidity was positively correlation and insignificant.

Tomato rust mite, Aceria lycopersici (Wolffenstein) recorded four and one peaks in the two seasons, respectively. All the tested factors had non significant effect and positive correlation in the two seasons, except of wind speed recorded negative correlation in the first season.

The red spider mite, Tetranychus spp. had three and five peaks in the two seasons, respectively. Statistical analysis recorded highly significant and positive relationship between mean numbers of Tetranychus spp. and the tested factors except of wind speed had negatively correlation in the first season . in the second season had positively and high significantly correlated with plant age after transplanting date, but temperature and wind speed showed positively correlation and significant effect.
\end{abstract}

Key words: Tomato rust mite, Aceria lycopersici, Tetranychus spp, temperature, relative humidity , Bemici tabaci, Thrips tabaci

\section{Introduction}

Cape gooseberry plant is tropical global distribution. Recently the plant become an important crop, it has been widely introduced into cultivation in other tropical, subtropical and even moderate temperature areas. It is grown in Egypt where it is known locally as harankash.
Cape gooseberry plant is a member of Solanace family is subjected to attack by a large number of insect and mite pests throughout the growing season, the sap-suking pests, Bemisia tabaci (Genn.), Thrips tabaci lind. and mites are commonly encountered as serious pest of various crops and sufficient to cause damage and high yield losses (Salati et.al., 2010; Canbay et. al., 2011; Azandeme-Hounmalon et.al.,2014 and Lokender Kashyap et.al.,2015) .In 
Egypt Afsah, 2015 surveyed 36 insect and mite species, that attack the Cape gooseberry plants in Qalubia Governorate. Other authors in different countries surveyed insect and mites that associated with cape gooseberry plants include: Heliothis assulta in Australia (Kirkpatrick, 1961); the crysomelid Lema bilineata; the potato aphid, Macrosiphaum euphorbiae and Heliothis subflexea, in Argentina (Bado et.al., 2000, 2001, and 2005); Helicoverpa armigera in India (Mehta et al., 1996; the dipteran Bactrocera latifrons in Hawaii (Liquido et. al., 1994); the hemipteran Acanthocoris scabrator (Koshy et.al.,1978); the lepidopteran Tuta absoluta in Italy (Tropea Garzia et al., 2009) and the mite Vasates lycopersici [Aculops lycopersici] in Australia (Smith and Saundees, 1956). Recently, cape gossybery is important vegetable product, where European consumer is casually eaten cap gossbery as fresh fruits, because its fruits are used as food and also in pharmaceutical industry (Lorenzi \&Matos, 2002 and Thomé \& Osaki, 2010).

\section{The present work was carried out to study:}

1- Population density of the mainly pests 2- Effect of plant age and some environmental conditions (temperature, relative humidity and wind speed) on population of some insects and mites

Therefore, Seasonal population fluctuation knowledge of insects and mites that attack cap gooseberry are important to define efficient methods and time of control.

\section{Materials and Methods}

Field experiments were carried out at the Experimental Farm of Plant Protection Research Station at Qaha, Qalubia Governorate, Plant Protection Research Institute, Agricultural Research Center, Egypt. Field experiment was conducted during two summer seasons 2012 and 2013 to study the effect of plant age and some weather factors on the population fluctuation of insects and mites that attacking Cape gooseberry plants.

The experimental area was $900 \mathrm{~m}^{2}$, divided into three replicates. Cape gooseberry was transplanting on $3^{\text {rd }}$ and $7^{\text {th }}$ of April and March in the first and second seasons, respectively. Normal agricultural practices were done without pesticide applications. Weekly sample of leaves (20 of each replicate) were collected at random. Sample was collected in paper bags to examine in laboratory by using stereomicroscope at the same day. All data were calculated as weekly mean number of whitefly immature stages and moving stages for both cotton thrips, tomato rust mite and the red spider mite / replicate.

Weekly means of maximum\& minimum temperature $\left({ }^{\circ} \mathrm{C}\right)$, maximum and minimum relative humidity (R.H. \%) and wind speed (meter/S.) were obtained from Central Laboratory for Agriculture Climate (Table 1). The weekly mean number of insects and mites subjected to statistical analysis with the physical factors of each previous week and plant age after transplantation. The explained variance $\%$ $(\mathrm{EV} \%)$ and simple correlation coefficient between the mean number of pest species \& both weather factors and plant age after transplantation were estimated by using SAS program computer (SAS Institute, 2003).

\section{Results and Discussion}

The experiment of seasonal abundance extend from April, $10^{\text {th }}$ till August, $7^{\text {th }}$ in the first seasons , while in the second season extended from March, $14^{\text {th }}$ till July, $11^{\text {th }} 2013$. The results of this study could be declared as follows :

\section{1-Cotton whitefly, Bemisia tabaci (Genn.): \\ Eggs:}

Data in Tables 1 and 2 indicate that in the first season 2012, the population of $B$ tabaci eggs recorded 6 peaks $(55.67,113.33,39.00,27.00,2.33$ and 21.67 eggs / 20 leaves) at April,24 $4^{\text {th }}$, May, $8^{\text {th }}$,May, $22^{\text {th }}$, June, $5^{\text {th }}$, June, $26^{\text {th }}$ and July, $31^{\text {st }}$. In the second season 2013 the population of $B$ tabaci eggs recorded 5 peaks at the dates April, $11^{\text {th }}$, April, $25^{\text {th }}$, May, $23^{\text {th }}$, June, $13^{\text {ed }}$ and July, $4^{\text {th }}$ with mean numbers of 54.00, 34.67, 28.00, 12.00 and 5.33 eggs / 20 leaves, respectively.

Also, data declared that the number of whitefly eggs fluctuated to give highest infestation rate (113.33 eggs / sample) in May, $8^{\text {th }} 2012$ and 54.00 eggs / sample in April, $11^{\text {th }} 2013$.

In this respect, Amaar et al.,2014 in Egypt, found that the number of B. tabaci eggs on phaseolus vulgaris plants had two peaks for both 2011 and 2012 seasons at Qalubia Governorate.

Statistical analysis of data indicated that, the relationship between mean numbers of whitefly eggs and Plant age after transplanting date, maximum. \& Minimum Temperature and wind speed were negative and highly significant except of wind speed 
had a positively effect. maximum. \& Minimum RH\% were negatively significant correlation in the first season of 2012 (Table 3).

In the second season, the effect of plant age after transplantation was negative and statistically significant. But maximum. \& Minimum Temperature were negative and highly significant effect, while maximum. \& Minimum RH\% and wind speed were showed negative and statistically insignificant, except of wind speed was positive effect. From previous data clear that, both temperature and plant age from transplanting played a significant rol in the population of whitefly eggs. The obtained results by Amaar et al.(2014) revealed significant negative effects of minimum and maximum temperature on numbers of $B$. tabaci eggs while relative humidity had insignificant positive effect during two season of 2011 and 2012.

\section{Nymphs:}

Data in Tables 1 and 2 show that population of $B$. tabaci nymph recorded 6 peaks and 5 peaks in the two experimental seasons on Cape gooseberry plants. Peaks of nymph population recorded 46.00, 51.33, $24.67,3.33,14.33$ and 28.33 nymph $/ 20$ leaves at the dates of May, $8^{\text {th }}$, May, $22^{\text {th }}$, June, $5^{\text {th }}$, June, $26^{\text {th }}$, July, $17^{\text {th }}$ and July, $31^{\text {st }} 2012$ in the first season, respectively. In the second season showed these peaks estimated at dates of March, $28^{\text {th }}$, May, $2^{\text {ed }}$, May, $23^{\text {rd }}$, June, $6^{\text {th }}$ and July $7^{\text {th }} 2013$, with the mean numbers of $27.33,26.00,33.33,13.33$ and 7.00 nymph $/ 20$ leaves, respectively. The highest population of B. tabaci nymph recorded on 49 and 77 days after transplanting date (Tables, 1and 2) in the two seasons, respectively. Amaar et al., 2014 in Egypt mentioned that whitefly nymph recorded two peaks at October, $17^{\text {th }} \&$ November, $21^{\text {st }}$ and October, $24^{\text {th }} \&$ November, $28^{\text {st }}$ in the 2011 and 2012 seasons at Qalubia Governorate, respectively.

Data in Table 3, clear that there are negatively and non significant correlation between all the tested factors and the mean numbers of nymph in the two successive seasons (2012 - 2013) except of wind speed that had positively and non significant in the first season ( $r=0.152)$ and showed, also, positively significant $(r=0.493)$ in the second season. The value of the explained variance (EV\%) of each one factors from the tested factors showed fluctuated values in the two season. The pooled EV\% recorded 26.02 and 44.05 in the two successive seasons , respectively . El-Mowafy, 2008 found that the plant age and maximum temperature had negative effect on the population of the whitefly nymphs during season of 2006, also in the season of 2007 plant age and RH\% had negative correlation. Amaar, et. al., 2014 found that, the effect of minimum and maximum temperature showed significant negative effects on the seasonal fluctuation of $B$. tabaci nymphs throughout both two seasons of 2011 and 2012, while the percentages of relative humidity had insignificant positive effect in both two seasons .

\section{Pupae:}

Tables 1 and 2 show that, B. tabaci pupae had 6 and 3 peaks at seasons 2012 and 2013, respectively. First season peaks recorded on April, $24^{\text {th }}$, May, $8^{\text {th }}$,

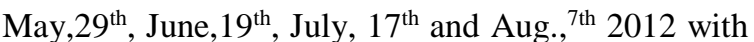
population density of $1.0,43.67,33.33,2.67,1.67$ and 1.0 pupae / 20 leaves, respectively. The second season had only three peaks at dates April, $4^{\text {th }}$, May, $2^{\text {nd }}$ and May, $30^{\text {rd }} 2013$, where the mean numbers of pupae recorded 9.33, 8.33 and 32.00 pupae / 20 leaves. Also, data indicate that the highest population of B. tabaci pupae estimated on May, $8^{\text {th }} 2012$ and May,30 ${ }^{\text {rd }} 2013$ (with mean numbers of 43.67 and 32.00 pupae / 20 leaves, respectively.) at thirty five and eighty four days after transplanting date and at 31.55 Max. Temp., 16.51 Min. Temp., 82.30 Max. RH\%, 38.69 Min. RH\% \& 3.57 wind speed and 33.26 Max. Temp., 17.47 Min. Temp., 80.04 Max. RH\% , 34.61 Min. RH\% \& 3.16 wind speed in the first and second seasons (Tables, 1 \& 2 ) , respectively. In the same filed El-Mowafy 2008 mentioned that, whitefly nymphs recorded two peaks and three peaks on potato during 2006 and 2007, respectively. In Egypt EL-Sayed et.al.,1991 mention that, period of high infestation rates on tomato, eggplant and pepper were August and September for summer plantation, October and November for winter plantation, and July and August for the early summer plantation.

Statistical analysis of the first season data (Table 3) revealed that all the tested factors had negative and non significant correlation with population of pupae except the wind speed showed positive and non significant correlation, where the $r$ value had relative high value (0.230).

While in the second season, plant age after transplanting date, Max. \& Min. Temp. and wind speed had positive and non significant correlation with value of $0.335,0.491 \& 0.458$ and 0.035 and the value of EV\% were 11.20, $24.08 \& 20.98$ and $0.12 \%$ , respectively. It is to mention that, the Max. and Min. relative humidity showed a negative correlation 
and non significant effect. In Egypt Maklad et.al., 2014 mention that, relative humidity was less effectively on population of $B$. tabaci on pepper plants during 2012 and 2013 seasons.

\section{2-Cotton thrips, Thrips Tabaci Lind.}

The primary infestation with cotton thrips in the first season appeared on the second inspection

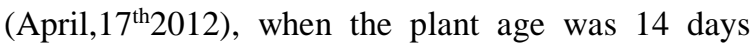
after transplanting date with mean numbers of 3.67 nymph and 15.00 adults / 20 leaves . But in the second season nymph of thrips appeared on the first inspection by mean numbers of 2.67 insects / 20 leaves, while the first appearance of adults occurred on second inspection with mean numbers of 15.00 and adults / 20 leaves at the 7 and 14 days after transplanting date, respectively.

\section{Nymphs:}

Data presented in Tables 1 and 2 illustrate that, population of cotton thrips nymphs recorded four and six peaks in the first and second season, respectively.

The data of the first season characterized by two highly peaks during first five inspection at dates April, 24 ${ }^{\text {th }}$ and May, $8^{\text {th }} 2012$ with mean numbers of 35.33 and 39.33 nymphs / 20 leaves, while the two rest peaks occurred at June, $12^{\text {th }}$ and June, $26^{\text {th }} 2012$ with low mean numbers of 1.67 and 3.33 nymphs / 20 leaves.

Six peaks were recorded in the second season, whereas the first peak had the highest population of nymphs with mean numbers of 19.33 , at the fourteenth day after transplanting date that associated with, 25.30 Max. Temp.,9.91 Min Temp., 80.84 Max. RH\%, 38.14 Min. RH\% and 3.21 Wind speed Tables 1 and 2.

Statistical analysis of data in Table 3 showed that the plant age after transplanting, Max. \& Min. temperature and wind speed recorded negative and highly significant correlation except of wind speed was positively effect, the $\mathrm{E} \mathrm{V} \%$ of the previous factors were $34.87,47.38 \& 45.66$ and $31.75 \%$, While Max. relative humidity was negative and insignificant and Min. relative humidity had negative and significant correlation with population of thrips nymphs during the first season. In the second season, plant age and Max. \& Min. Temp. recorded negative and significant correlation and its EV \% recorded of 31.56, 29.97 and 30.28 \%, respectively. But, Max. \& Min. R H \% and wind speed were negative non significant correlation except of wind speed was positively effect.

\section{Adults:}

Data in Table 1 show that, the population of thrips adults began low at the second inspection date and amounted 15.00 adults / 20 leaves then increased to reach its maximum level of 80.33 adults / 20 leaves on May, $8^{\text {th }} 2012$ at 35 days after transplanting date and 31.55 Max., 16.51 Min. Temp., 82.30 Max. ,38.69 Min. RH\% and 3.87 Wind speed . After that, the adults of cotton thrips fluctuated to show two various peaks on June, $12^{\text {th }}$ and June, $26^{\text {th }}$ with mean numbers of $2.00 \& 15.00$ adults / 20 leaves at $70 \&$ 84 days after transplanting date and $32.87 \& 35.01$ Max., 17.70 \& 20.36 Min. Temp.; 82.51\& 85.58 Max., $38.30 \& 38.68$ Min. relative humidity ; $2.91 \&$ 2.64 wind speed, respectively. In the second season , population of cotton thrips adults had four peaks (Tables 2) with mean numbers of 2.00; 24.00;9.67 and 2.00 adult / 20 leaves that associated with 25.3Max.\& 9.91Min. Temp. , 80.84 Max. \& 38.14 Min. relative humidity and $3.21 \mathrm{Wind}$ speed ; 25.51Max.\& 11.59Min. Temp. , 83.33 Max. \& 39.21 Min. relative humidity and $3.31 \mathrm{Wind}$ speed ; 30.47Max.\& 13.53Min. Temp. , 85.67 Max. \& 36.73 Min. relative humidity and $3.97 \mathrm{Wind}$ speed and 34.59Max.\& 18.30 Min. Temp., 83.79 Max. \& 36.31 Min. relative humidity and $3.45 \mathrm{Wind}$ speed on March,21 ${ }^{\text {st }} ;$ April, $11^{\text {th }} ;$ May, $2^{\text {nd }}$ and Jun., $6^{\text {th }}$ at $14 ; 35$; 56 and 91days after transplanting date, respectively. EL-Mowafy (2008) recorded that, population of Thrips Tabaci had two and three peaks in the potato summer plantation (2006 and 2007), respectively.In Chane Ho and China, 1992 recorded that the population of Thrips palmi on aubergines peaked in May, also in Egypt El- Laithy et al., 2013 stated that the highest population density of Thrips tabaci during the fall was recorded on sweet pepper.

Statistical analysis of the first season data about the effect of the tested factors on the mean number of adults / 20 leaves showed the same trend of the thrips nymphs (Table 2). Also, in the second season plant age after transplantation and Max. \& Min. temperature had the same trend of the thrips nymph, where recorded negatively correlation and insignificant effect, except Max. temperature recorded significant effect.Also, Max. and min. R $\mathrm{H} \%$ were recorded positive and non significant while the wind speed showed negative and insignificant. Data in Table (3) was showed that the maximum and minimum temperature were recorded the highest $\mathrm{E} \mathrm{V}$ $\%$ in two season (34.78 \& 34.36) and (28.91 \& 22.64), respectively. These results partial agreement with El-Mowafy, 2008.

\section{3- Tomato rust mite, Aceria lycopersici (Wolffenstein)}

Tables 1\&2 show Population fluctuation of tomato russet mite during two successive seasons 2012 and 2013. 
In the first season, tomato rust mite population recorded four peaks at $63,77,105$ and 126 days after transplanting date and on Jun., $5^{\text {th }}$, Jun., 19 ${ }^{\text {th }}$, Jul., $17^{\text {th }}$ and Aug., $7^{\text {th }} 2012$ with mean numbers of $1470.33,2530.00,908.33$ and 546.67 individuals / 20 leaves. On the other hand, the second season had only one peak recorded on Jun.,20 2013 at plant age 105 days after transplanting date with mean number of 6556.67 / 20 leaves.

It was obvious that the transplanting date in the two seasons were not fixed and the initial appearance of tomato russet mite occurred in closed date on May, $1^{\text {st } 2012}$ and May, $9^{\text {th }} 2013(0.67$ and 0.33 individuals / 20 leaves with Max. Tempe. of $28.64{ }^{\circ} \mathrm{C}$ and $30.61{ }^{\circ} \mathrm{C}$ ), respectively, tomato rust mite recorded jumping increase at closely date (May, $22^{\text {th }}$ 2012 and May,23 ${ }^{\text {rd }}$ 2013) where recorded 249.33 and 338.0 individuals / 20 leaves, respectively. This reflect that, the appearance and actually existence of tomato rust mite was related with minimum and maximum temperature in the two seasons (16.85 and 31.69 )and (16.90 and 31.74), respectively. Also in the two seasons the highest peak recorded approximately in the same time at Jun., $19^{\text {th }} 2012$ and Jun., 20 ${ }^{\text {th }} 2013$, with mean number of 2530.0 and 6556.67 individuals / 20 leaves. The Min. and Max. Temp. reached to ( 19.04 and 33.70) and (17.77 and 30.96) in the two studied seasons. . In this respect Hncal et.al. (2002) found that A. lycopersici began to appear at 26.1 and $28.3{ }^{\circ} \mathrm{C}$ when the first green tomato was seen in the field and the population density of A. lycopersici reached the highest level whene the green tomatoes were abundant,the population density of the pest was increased during harvest and the pest was found to be dense at below and middle leaves. Statistical analysis proved that plant age after transplantation, Max. \& Min. Temp., Max. \& Min. R H \% and wind speed had positive and insignificant effect in two seasons except of wind speed was negatively effect in the first season only. The E V \% values of these factors in the first season recorded $11.47,18.45 \& 17.90,12.93 \& 16.88$ and $3.58 \%$, while in the second season were 18.53 , $2.17 \& 6.66,5.01 \& 16.67$ and $3.04 \%$, respectively. The pooled E V \% of tested factors were 31.07 and 61.84 in two seasons 2012 and 2013, respectively.

These results agree with obtained by Lokender kashyab et al., 2015 who stated that correlation coefficient (r) between number of tomato russet mite , Aculops lycopersici on tomato plants had positive correlation with temperature.

\section{4- The red spider mite, Tetranychus spp.}

In general, population of Tetranychus spp., characterized by two phases. The first phase started from first inspection (April, 10 $0^{\text {th }}$ 2012) till tenth inspection (Jun.,12 ${ }^{\text {th }}$ 2012) in the first season, while in the second season from first inspection
(March,14 ${ }^{\text {th }} 2013$ ) till twelfth inspection (May, 30 rd 2013). The first phase characterized with slow fluctuation. The second phase started from 11 to 18 inspections at dates of Jun., $19^{\text {th }}$ to Aug., $7^{\text {th }} 2012$ in the first season, and from 13 to 18 inspection at the date of Jun., $6^{\text {th }}$ to Jul., $11^{\text {th }} 2013$, in the second season. Second phase characterized by highly population fluctuation. The red spider mite had three and five peaks at May, $8^{\text {th, Jul.,24 }}{ }^{\text {th }} \&$ Aug., $7^{\text {th }} 2012$ and April, $4^{\text {th }}$, April, $25^{\text {th }}$, Jun. $6^{\text {th }}$, Jun.,20 $0^{\text {th }} \&$ Jul., $11^{\text {th }}$ 2013 with mean numbers $(9.33,234.33$ \& 187.00 individuals / 20 leaves) and (2.67, 6.00, 28.67, 43.33 \& 151.33 individuals / 20 leaves) for two successive seasons, respectively, Tables 1 and 2. In China Ho and Chen, 1992 mentioned that the first peak of spider mite, T.cinnabarinus on eggplant occurred in May-July. In Egypt Amaar et. al.,2014 found that, $T$. urticae had two peaks on phaseolus vulgaris plants during both 2011 and 2012 seasons. In Turkiye, Cobanoglu and Kumral , 2014 found that, the population density of $T$. urticae on tomato began to increase in late- May and peaked three times in midJune, late-July and mid-September in Bursa. Also in Ankara, this pest emerged in late-July and occurred three peaks in mid-August, early September and Mid-October.

Data in Table 3, proved to be highly significant \& positive relationship between Tetranychus spp. population and the tested factors except of wind speed had negatively correlation in the first season. In the second season, data clearly indicate that number of Tetranychus spp. was positively and high significantly correlated with plant age, but the effect of both Max. Temp.and maximum $\&$ minimum relative humidity recorded positive and statistically insignificant, while Min. Temp. and wind speed showed positively and significantly correlation. The pooled EV\% recorded 76.42 and 42.58 in the two seasons, respectively.

In both seasons, data was indicated that the plant age after transplantation was played important and significant role for the population of Tetranychus spp., where the EV\% had 74.18 and $34.80 \%$ in the both seasons, respectively.

Kumar et al (2013) stated that the population of $T$. urticae on aubergine was positively correlated with maximum temperature and negatively correlated with relative humidity but the Min. temperature and wind velocity had no significant effect, also the same author in 2013 studied the effects of temperature and relative humidity on the biology of T.urtice reared on aubergine under laboratory conditions. Who found that, high temperature $\left(30{ }^{\circ} \mathrm{C}\right)$ and low relative humidity $(60 \%)$ reduced the duration of life cycle by 2-3 days, also the pre ovipositon and oviposition periods lasted 1.5-2.6 and 10-13 days, respectively. 
Table 1. population of some sap- sucking pests attacking cape gooseberry at Qaha district, plant age after transplanting date and some weather factors during first season of 2012.

\begin{tabular}{|c|c|c|c|c|c|c|c|c|c|c|c|c|c|}
\hline \multirow{3}{*}{$\begin{array}{l}\text { Date of } \\
\text { inspection }\end{array}$} & \multirow{3}{*}{ P.A.T. } & \multicolumn{7}{|c|}{ Mean numbers / 20 leaves } & \multirow{2}{*}{\multicolumn{5}{|c|}{ Weakly means of som weather factors }} \\
\hline & & \multicolumn{3}{|c|}{ Bemisia tabaci } & \multicolumn{2}{|c|}{ Thrips tabaci } & \multirow{2}{*}{ A. lycopersici } & \multirow{2}{*}{ Tetranychus spp. } & & & & & \\
\hline & & Eggs & Nymphs & Pupae & Nymphs & Adult & & & MAX_TEMP & MIN_TEMP & MAX_RH & MIN_RH & W_S \\
\hline $10 / 04 / 2012$ & 7 & 40.00 & 2.00 & 2.00 & 0.00 & 0.00 & 0.00 & 0.00 & 29.57 & 13.25 & 76.99 & 34.24 & 2.96 \\
\hline 17/04/ & 14 & 52.00 & 5.00 & 0.33 & 3.67 & 15.00 & 0.00 & 1.00 & 29.01 & 13.06 & 78.42 & 29.64 & 2.95 \\
\hline 24/04/ & 21 & 55.67 & 5.00 & 1.00 & 35.33 & 54.33 & 0.00 & 2.00 & 28.70 & 11.90 & 77.84 & 30.71 & 3.39 \\
\hline $01 / 05 /$ & 28 & 37.67 & 16.67 & 0.67 & 32.33 & 80.33 & 0.67 & 4.67 & 28.64 & 12.68 & 77.51 & 35.71 & 3.28 \\
\hline 08/05/ & 35 & 113.33 & 46.00 & 43.67 & 39.33 & 80.33 & 28.67 & 9.33 & 31.55 & 16.51 & 82.30 & 38.69 & 3.57 \\
\hline $15 / 05 /$ & 42 & 30.67 & 26.00 & 7.33 & 5.33 & 46.67 & 63.00 & 4.33 & 31.01 & 15.96 & 83.21 & 35.60 & 2.75 \\
\hline $22 / 05 /$ & 49 & 39.00 & 51.33 & 32.67 & 2.33 & 14.33 & 249.33 & 2.33 & 31.69 & 16.85 & 77.93 & 33.50 & 2.69 \\
\hline $29 / 05 /$ & 56 & 3.33 & 20.33 & 33.33 & 1.00 & 0.33 & 1211.00 & 1.00 & 32.58 & 18.19 & 78.27 & 35.32 & 3.01 \\
\hline $05 / 06 /$ & 63 & 27.00 & 24.67 & 1.00 & 0.33 & 0.33 & 1470.33 & 1.67 & 32.07 & 17.76 & 80.61 & 40.14 & 3.52 \\
\hline $12 / 06 /$ & 70 & 4.00 & 7.00 & 0.33 & 1.67 & 2.00 & 867.00 & 4.67 & 32.87 & 17.70 & 82.51 & 38.30 & 2.91 \\
\hline $19 / 06 /$ & 77 & 1.00 & 2.67 & 2.67 & 1.00 & 1.00 & 2530.00 & 34.67 & 33.70 & 19.04 & 86.81 & 41.86 & 2.71 \\
\hline $26 / 06 /$ & 84 & 2.33 & 3.33 & 1.00 & 3.33 & 15.00 & 802.33 & 94.67 & 35.01 & 20.36 & 85.58 & 38.68 & 2.64 \\
\hline 03/07/ & 91 & 1.33 & 1.00 & 0.67 & 2.67 & 3.00 & 855.33 & 104.67 & 33.96 & 20.56 & 87.36 & 45.82 & 3.09 \\
\hline $10 / 07 /$ & 98 & 1.67 & 2.00 & 1.00 & 2.33 & 1.67 & 882.00 & 109.67 & 33.96 & 20.56 & 87.36 & 45.82 & 3.09 \\
\hline 17/07/ & 105 & 8.00 & 14.33 & 1.67 & 1.67 & 1.33 & 908.33 & 114.00 & 34.99 & 21.81 & 86.75 & 43.46 & 2.79 \\
\hline $24 / 07 /$ & 112 & 17.33 & 7.33 & 1.33 & 1.00 & 0.67 & 636.33 & 234.33 & 35.67 & 21.82 & 86.19 & 43.47 & 2.74 \\
\hline $31 / 07 /$ & 119 & 21.67 & 28.33 & 0.67 & 1.00 & 0.00 & 528.67 & 140.00 & 35.06 & 21.25 & 86.53 & 44.69 & 2.78 \\
\hline 07/08/ & 126 & 11.00 & 15.00 & 1.00 & 0.00 & 0.00 & 546.67 & 187.00 & 35.29 & 21.88 & 87.25 & 41.59 & 2.53 \\
\hline
\end{tabular}

P.A.T. = plant age after transplanting date 
Table 2. population of some sap-sucking pests attacking cape gooseberry at Qaha district, plant age after transplanting date and some weather factors during second season of 2013

\begin{tabular}{|c|c|c|c|c|c|c|c|c|c|c|c|c|c|}
\hline \multirow{3}{*}{$\begin{array}{l}\text { Date of } \\
\text { inspection }\end{array}$} & \multirow{3}{*}{ P.A.T. } & \multicolumn{7}{|c|}{ Mean numbers / 20 leaves } & \multirow{2}{*}{\multicolumn{5}{|c|}{ Weakly means of som weather factors }} \\
\hline & & \multicolumn{3}{|c|}{ Bemuse tabaci } & \multicolumn{2}{|c|}{ Thrips tabaci } & \multirow{2}{*}{$\begin{array}{r}A . \\
\text { lycopersici }\end{array}$} & \multirow{2}{*}{$\begin{array}{l}\text { Tetranychus } \\
\text { spp. }\end{array}$} & & & & & \\
\hline & & Eggs & Nymphs & Pupae & Nymphs & Adults & & & MAX_TEMP & MIN_TEMP & MAX_RH & MIN_RH & W_S \\
\hline $14 / 03 / 2013$ & 7 & 9.00 & 2.67 & 0.00 & 2.67 & 0.00 & 0.00 & 0.33 & 27.21 & 12.41 & 76.99 & 33.37 & 3.45 \\
\hline $21 / 03 /$ & 14 & 10.00 & 5.33 & 0.67 & 19.33 & 2.00 & 0.00 & 0.67 & 25.30 & 9.91 & 80.84 & 38.14 & 3.21 \\
\hline $28 / 03 /$ & 21 & 23.33 & 27.33 & 2.00 & 2.67 & 0.67 & 0.00 & 1.33 & 26.87 & 9.91 & 81.21 & 31.00 & 3.43 \\
\hline 04/04/ & 28 & 24.67 & 18.00 & 9.33 & 4.00 & 4.67 & 0.00 & 2.67 & 29.81 & 13.63 & 77.90 & 29.09 & 3.02 \\
\hline $11 / 04 /$ & 35 & 54.00 & 13.67 & 3.33 & 6.33 & 24.00 & 0.00 & 1.67 & 25.51 & 11.59 & 83.33 & 39.21 & 3.31 \\
\hline $18 / 04 /$ & 42 & 23.67 & 2.33 & 0.67 & 2.00 & 19.67 & 0.00 & 1.00 & 24.80 & 9.83 & 87.73 & 41.56 & 2.80 \\
\hline $25 / 04 /$ & 49 & 34.67 & 25.33 & 1.33 & 4.67 & 9.00 & 0.00 & 6.00 & 24.59 & 9.60 & 86.37 & 38.20 & 2.92 \\
\hline $02 / 05 /$ & 56 & 27.00 & 26.00 & 8.33 & 1.00 & 9.67 & 0.00 & 1.00 & 30.47 & 13.53 & 85.67 & 36.73 & 3.97 \\
\hline 09/05/ & 63 & 21.67 & 10.67 & 2.00 & 1.67 & 5.00 & 0.33 & 0.67 & 30.61 & 15.74 & 88.40 & 41.13 & 3.00 \\
\hline $16 / 05 /$ & 70 & 17.33 & 13.33 & 6.67 & 1.33 & 4.67 & 9.33 & 1.00 & 30.37 & 16.00 & 84.99 & 37.10 & 3.21 \\
\hline $23 / 05 /$ & 77 & 28.00 & 33.33 & 28.00 & 0.00 & 0.67 & 338.00 & 1.67 & 31.74 & 16.90 & 81.27 & 37.03 & 3.06 \\
\hline $30 / 05 /$ & 84 & 1.33 & 7.33 & 32.00 & 0.00 & 2.00 & 460.33 & 4.67 & 33.26 & 17.47 & 80.04 & 34.61 & 3.16 \\
\hline 06/06/ & 91 & 7.33 & 13.33 & 7.33 & 4.00 & 2.00 & 2588.67 & 28.67 & 34.59 & 18.30 & 83.79 & 36.31 & 3.45 \\
\hline $13 / 06 /$ & 98 & 12.00 & 6.00 & 1.33 & 0.67 & 0.67 & 2986.00 & 8.67 & 33.91 & 17.54 & 84.94 & 35.61 & 3.10 \\
\hline $20 / 06 /$ & 105 & 0.67 & 5.33 & 0.00 & 0.00 & 0.00 & 6556.67 & 43.33 & 30.96 & 17.77 & 87.53 & 44.41 & 2.86 \\
\hline $27 / 06 /$ & 112 & 0.67 & 0.67 & 0.00 & 0.67 & 0.00 & 1957.33 & 10.67 & 33.04 & 19.69 & 88.80 & 42.06 & 2.49 \\
\hline $04 / 07 /$ & 119 & 5.33 & 0.67 & 0.00 & 0.67 & 0.00 & 1279.33 & 31.33 & 33.73 & 20.37 & 87.20 & 40.71 & 2.33 \\
\hline $11 / 07 /$ & 126 & 1.00 & 7.00 & 0.00 & 0.00 & 0.00 & 484.00 & 151.33 & 33.59 & 20.73 & 88.04 & 42.51 & 2.48 \\
\hline
\end{tabular}


Table 3. Effect of plant age and some climatic factors on the population density of some sap-sucking pests infesting Cape gooseberry plants at Qaha district during two summer seasons of 2012 and 2013

\begin{tabular}{|c|c|c|c|c|c|c|c|c|c|c|c|c|c|c|}
\hline \multicolumn{15}{|c|}{ First season of 2012} \\
\hline \multirow{2}{*}{ Pests } & \multicolumn{6}{|c|}{ Bemisia tabaci } & \multicolumn{4}{|c|}{ Thrips tabaci } & \multirow{2}{*}{\multicolumn{2}{|c|}{ Aceria lycopersic }} & \multirow{2}{*}{\multicolumn{2}{|c|}{ Tetranychus spp. }} \\
\hline & \multicolumn{2}{|c|}{ Eggs } & \multicolumn{2}{|c|}{ Nymphs } & \multicolumn{2}{|c|}{ Pupae } & \multicolumn{2}{|c|}{ Nymphs } & \multicolumn{2}{|c|}{ Adults } & & & & \\
\hline $\begin{array}{l}\text { Tested } \\
\text { factors }\end{array}$ & $\mathrm{r}$ & $\mathrm{EV} \%$ & $\mathrm{r}$ & $\mathrm{EV} \%$ & $\mathrm{R}$ & $\mathrm{EV} \%$ & $\mathrm{r}$ & $\mathrm{EV} \%$ & $\mathrm{r}$ & $\mathrm{EV} \%$ & $\mathrm{r}$ & $\mathrm{EV} \%$ & $\mathrm{r}$ & $\mathrm{EV} \%$ \\
\hline P.A.T. & $-0.620 * *$ & 38.39 & -0.112 & 1.26 & -0.273 & 7.45 & $-0.591 * *$ & 34.87 & $-0.542 *$ & 29.43 & 0.339 & 11.47 & $0.861 * *$ & 74.18 \\
\hline Max Temp. & $-0.595 * *$ & 35.46 & -0.087 & 0.75 & -0.107 & 1.15 & $-0.688 * *$ & 47.38 & $-0.590 * *$ & 34.78 & 0.339 & 18.45 & $0.805 * *$ & 64.77 \\
\hline Min. Temp. & $-0.595 * *$ & 35.39 & -0.049 & 0.24 & -0.128 & 1.65 & $-0.676 * *$ & 45.66 & $-0.586 * *$ & 34.36 & 0.423 & 17.90 & $0.797 * *$ & 63.50 \\
\hline Max RH\% & $-0.496 *$ & 24.63 & -0.245 & 5.98 & -0.248 & 6.17 & -0.449 & 20.17 & -0.372 & 13.81 & 0.360 & 12.93 & $0.771 * *$ & 59.38 \\
\hline Min. RH\% & $-0.492 *$ & 24.19 & -0.150 & 2.25 & -0.323 & 10.47 & $-0.465^{*}$ & 21.66 & -0.408 & 16.65 & 0.411 & 16.88 & $0.720 * *$ & 51.82 \\
\hline $\begin{array}{l}\text { Wind } \\
\text { velocity }\end{array}$ & $0.576 * *$ & 33.29 & 0.152 & 2.30 & 0.230 & 5.28 & $0.563 * *$ & 31.75 & $0.520 *$ & 27.02 & -0.189 & 3.58 & $-0.484 * *$ & 23.40 \\
\hline Pooled EV\% & & 53.80 & & 26.02 & & 52.27 & & 65.43 & & 51.64 & & 31.07 & & 76.42 \\
\hline \multicolumn{15}{|c|}{ Second season of 23} \\
\hline \multirow{2}{*}{ Pests } & \multicolumn{6}{|c|}{ Bemisia tabaci } & \multicolumn{4}{|c|}{ Thrips tabaci } & \multirow{2}{*}{\multicolumn{2}{|c|}{ Aceria lycopersic }} & \multirow{2}{*}{\multicolumn{2}{|c|}{ Tetranychus spp. }} \\
\hline & \multicolumn{2}{|c|}{ Egg } & \multicolumn{2}{|c|}{ Nymphs } & \multicolumn{2}{|c|}{ Pupae } & \multicolumn{2}{|c|}{ Nymphs } & \multicolumn{2}{|c|}{ Adults } & & & & \\
\hline $\begin{array}{l}\text { Tested } \\
\text { factors }\end{array}$ & $\mathrm{R}$ & $\mathrm{EV} \%$ & $\mathrm{r}$ & $\mathrm{EV} \%$ & $\mathrm{R}$ & $\mathrm{EV} \%$ & $\mathrm{r}$ & $\mathrm{EV} \%$ & $\mathrm{r}$ & $\mathrm{EV} \%$ & $\mathrm{r}$ & $\mathrm{EV} \%$ & $\mathrm{r}$ & $\mathrm{EV} \%$ \\
\hline P.A.T. & $-0.550 *$ & 30.21 & -0.296 & 8.75 & 0.335 & 11.20 & $-0.562 *$ & 31.56 & -0.255 & 6.48 & 0.431 & 18.53 & $0.590 * *$ & 34.80 \\
\hline Max Temp. & $-0.65 * *$ & 37.77 & -0.188 & 3.54 & 0.491 & 24.08 & $-0.547 *$ & 29.97 & $-0.538^{*}$ & 28.91 & 0.147 & 2.17 & 0.406 & 16.49 \\
\hline Min. Temp. & $-0.6^{* *}$ & 40.38 & -0.188 & 11.19 & 0.458 & 20.98 & $-0.550 *$ & 30.28 & -0.476 & 22.64 & 0.258 & 6.66 & $0.539 *$ & 29.09 \\
\hline Max RH\% & -0.1 & 1.63 & -0.253 & 6.41 & -0.350 & 12.24 & -0.320 & 10.24 & 0.347 & 12.01 & 0.224 & 5.01 & 0.373 & 13.89 \\
\hline Min. RH\% & -0.2 & 4.45 & -0.440 & 19.35 & -0.252 & 6.33 & -0.110 & 1.22 & 0.334 & 11.13 & 0.408 & 16.67 & 0.427 & 18.21 \\
\hline $\begin{array}{l}\text { Wind } \\
\text { velocity }\end{array}$ & 0.37 & 14.27 & $0.493^{*}$ & 24.28 & 0.035 & 0.12 & 0.210 & 4.40 & -0.046 & 0.21 & 0.408 & 3.04 & $0.426^{*}$ & 22.29 \\
\hline Pooled EV\% & & 52.67 & & 44.05 & & 48.81 & & 49.88 & & 43.97 & & 61.84 & & 42.58 \\
\hline
\end{tabular}

$\mathrm{E} \mathrm{V} \%=$ Explained variance $\%$

P.A.T. = plant age after transplanting date . 


\section{Conclusion}

The previous data was indicated that $B$. tabaci immature stages and thrips moving stages are more dominant at the first half of plant age (vegetative and initial flowering stages), while highest number of Aceria lycopersici and Tetranychus spp. at the second half of plant age (flowering and fruiting stages), this may be related to Cape gooseberry content and needing of each pest, in addition to effect of temperature ${ }^{\circ} \mathrm{C}$.

\section{References}

Afsah, A. F.E., 2015. Survey of insects \& mite associated Cape gooseberry plants (Physalis peruviana L.) and impact of some selected safe materials against the main pests.Annals of Agric. Seien.( under press).

Amaar, M.I.; S.A. EL- Rfai; R.,S. A. Rashwan and M. F. A. H. Hegab, 2014. population dynamics and control of certain pests infesting green bean (Phaseolus vulgaris L.) at Qalubia Governorate, Egypt. Egypt. J. Agric. Res., 9 (3):921 - 933.

Azandeme-Hounmalon,G.Y.; S. Fellous;S. Kreiter; K.K.M. Fiaboe;S. Subramanian; M. Kungu and T. Martin, 2014.Dispersal behavior of Tetranychus evansi and T. urticae on Tomato at several spatial scales and densities: implications for integrated pest management. PLoS ONE, 9 (4).

Bado, S.G.; A.M.Cerri and F. Vilella, 2005. Insectile fauna associated with two species of Physalis (Solanaceae) cultures in Argentine. (Fauna insectil asociada a cultivos de dos especies de Physalis (Solanaceae) en Argentina.) Boletín de Sanidad Vegetal, Plagas, 31(3):321-333.

Bado SG; A.M. Cerri; F. Vilella and A. Molina, 2000. Aspects of morphology, biology and feeding of Lema bilineata (Germ) (Coleoptera: Chrysomelidae) on Physalis peruviana L. (Aspectos morfológicos, biológicos y de ingesta de Lema bilineata (Germ) (Coleoptera: Chrysomelidae) sobre Physalis peruviana L.) Boletín de Sanidad Vegetal, Plagas, 26(1):5-10.

Bado S.G.; A.M.Folcia; A.M. Cerri and F.Vilella, 2001. Population parameters of Macrosiphum euphorbiae (Thomas) (Homoptera: Aphididae) in Physalis peruviana (L.) (Solanaceae) crops. Revista de la Facultad de Agronomía (Universidad de Buenos Aires), 21(3):265-269.

Canbay, A.; O. Bozbek; H. Alc; I. F. Cakrbay, 2011. Determination and population development of harmful pests on the tomato and cucumber greenhouses in Erzincan province. Bitki Koruma Bulteni, 51(2):119-146.

Cobanoglu, S. and N.A. Kumral, 2014. The biodiversity and population fluctuation of plant parasitic and beneficial mite species (Acari) in tomato field of Ankara, Bursa and Yalova provinces (Turkish). Turkiye Entomoloji Dergisi; 38 (2):197-214.

El-Laithy,A.Y.M.; E.M.A.Elseedy; M.Y. El-Kholi ; M.M. Abou-Ellela and Z.Svobodova , 2013. Population dynamic of major insect and mite pests and control on sweet pepper grown in net house in Egypt.IOBC/WPRS Bulletin, 93 :3138.

El- Mowafy, H., 2008. Ecological and Biological studies of som pests associated with potato plants at Dakhlia Governorate.M.Sc.Thesis, Fac.Science (Girls) Al-Azhar Univ. 186 pp.

EL-Sayed, A.M.; F.F. Shalaby and A.A. AbdelGawad, 1991. Ecological studies on Bemisia tabaci (Gennadius) (Hemiptera-Homoptera: Aleyrodidae) infesting different host plants 1Fluctuation and population density of Bemisia tabaci on different host plants. Egypt. J. Agric. Res., 69 (1) : 193-207.

Hncal,P.; N. Yasaraknc and I. Cnarl, 2002. The researches on the population developments of Aculops lycopersici(Massee) (Acarina: Eriophyidae) and its natural enemies, the chemical control of the pest in Izmir. [Turkish].itki Koruma Bulteni. 42 (1/4): 9-22.

Ho,C.C. and W.H. Chen, 1992. Species survey of spider mites and seasonal occurrence of Thrips palmi, Chlorita biguttula biguttula and Tetranychus cinnabarinus on eggplant. Chinese Jourinal of Entomology. 12 (4)|:259-268.

Kirkpatrick,T.H., $1961 . \quad$ Comparative morphological studies of Heliothis species (Lepidoptera: Noctuidae) in Queensland. Queensland Journal of Agricultural Science, 18:179-194.

Koshy G.; A.Visalakshy and Nair MRGK, 1978.Acanthocoris scabrator Fabr. a new pest of mango. Current Science, 47(4):129-130

Kumar, S. V.; C. Chinniah; C. Muthiah; P. Sivasubramanian, 2013. Influence of temperature on the biology of two spotted spider mite, Tetranychus urticae Koch. on brinjal. Current Biotica; 2013. 7(3):236-240.

-2013.Influence of abiotic factors on two spotted spider mite population in eggplant. Current Biotica; 2013. 7(3):246-250. 
Liquido,N. J.; E.J..Harris and L.A. Dekker, 1994. Ecology of Bactrocera latifrons (Diptera: Tephritidae) populations: host plants, natural enemies, distribution, and abundance. Annals of the Entomological Society of America, 87(1):71-84

Lokender Kashyab; D.C.Sharma and A. K. Sood, 2015. Infestation and management of russet mite, Aculops lycopersici in tomato, Solanum lycopersicum under protected environment in north - western India. Environment and Ecology .33 (1):87-90

Lorenzi, H. and F.J.A. Matos, 2002. Plantas Medicinais no Brasil: nativas e exóticas cultivadas. Instituto Plantarum de Estudos da Flora, Nova Odessa, 512p.

Maklad, A.M.M.;S. A.Yassin and Y.A. El-Ghafar, 2014. Influence of certain climatic factors on some major pepper pests under Egyption conditions.Egyptian Academic Journal of Biological Sciences: Entomology 7 (1): 31-37.

Mehta P.K.; Kashyap, N.P.; S.S.Thakur, 1996. The Cape gooseberry (Physalis peruviana Linn.) a new host of gram caterpillar in Himachal Pradesh. Insect Environment, 2(3):84.

Salati, R.; M.Shore ; A. Briggs; J. Calderon; M. R. Rojas; L. F. Chen; R. L. Gilbertson and M. Palmieri, 2010. First report of Tomato yellow leaf curl virus infecting tomato, tomatillo, and peppers in Guatemala. Plant Disease, 94(4):482-483.

SAS Institute, 2003. SAS version 9.1. SAS institute Inc, Cory, NC, VSA.

Smith, W.A. and G.W.Saunders, 1956. Tomato mite control. Queensland Journal of Agricultural Science, 13:63-65.

Thome, M. \& F. OSAKI, 2010. Nitrogen, phosphorus and potassium fertilization results on Physalis spp. yeld. Rev. Acad. Ciênc. Agrár. Ambient. 8(1):11-18

Tropea Garzia G., 2009. Physalis peruviana L. (Solanaceae), a host plant of Tuta absoluta in Italy. IOBC/WPRS Bulletin [Proceedings of the IOBC/WPRS Working Group "Integrated Control in Protected Crops", Crete, Greece, 611 September 2009.], 49:231-232. 


\title{
الوفره العديه لبعض الافات الماصه للعصاره على نبات الحرنكش، .Physalis peruviana L
}

\author{
عبد الجابر فتوح السيد عفصه \\ معهد بحوث وقايه النبات 7 شارع نادى الصبد ، دقى ،جيزه، مصر
}

تم دراسه تاثير بعض العوامل (عمر النبات من بعد الثنل ، درجه الحراره العظمى والصغرى ،الرطوبه النسبيه العظمى والصغرى و سرعه الرياح) على تعداد بعض الافات الماصه للعصاره على نبات الحرنكش بمنطقه قها بمحافظه القليوبيه وذلك فى موسمى زراعه 2012 و و 2013 ـ سجل تعداد كلاً من بيض الذبابه وحوريات الذبابه البيضاء وجود 6 و 5 قمم عدديه لكل منها طول موسمى الدراسه على النوالى ـ كانت العلاقه بين عدد البيض للذبابه البيضاء وعمر النبات بعد الشتل وكذلك درجات الحراره العظمى والصغرى علاقه عاليه المعنويه سالبه بنما كانت

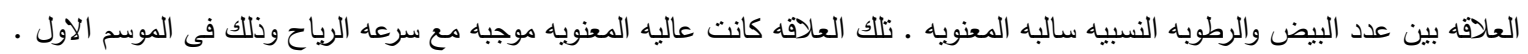
وقد اظهرت نتائج الموسم الثانى وجود علاقه معنويه سالبه بين كل من عدد البض وعمر النبات بعد الثنل بينما كانت تلك العلاقه عاليه المعنويه سالبه مع درجتى الحراره العظمى والصغرى وسالبه غير معنويه مع الرطوبه النسبيه ـ بينما كانت غير معنويه موجبه مع سرعه بهابه الرياح • وكانت العلاقه بين اعداد حوريات الذبابه البيضاء والعوامل المختبره سالبه غيرمعنويه فى كلا الموسمين ، فيما عدا سرعه الرياح كانت العلاقه موجبه وغير معنويه فى الموسم الاول ومعنويه فى الموسم الثانى. وقد سجلت اعداد عذارى الذبابه البضاء 6 و 3 قمم عدديه في الموسمين على التوالى وكانت العلاقه غير معنويه بين كل من العوامل المختبره واعداد العذاره. سجلت اعداد حوريات تربس القطن 4 و 6 قمم عدديه فى موسمى الزراعه على التوالى وقد أظهر التحليل الاحصائى فى الموسم الاول علاقه عاليه المعنويه سالبه الاتجاه بين اعداد تلك الحوريات وجميع العوامل المختبره فيما عدا سرعه الرياح فكانت ذات علاقهه موجبه . وكانت الرطوبه النسبيه العظمى غير معنويه و كذللك الرطوبه النسبيه الصغرى معنويه الناثير • وفى العام الثانى كانت العلاقه بين اعداد الحوريات وجميع العوامل المختبره معنويه سالبه التاثير فيما عدا الرطوبه النسبيه كانت غير معنويه وسرعه وسيه الرياح غير معنويه موجبه. سجلت اعداد حشره التربس الكامله 3 و 4 قم عدديه فى الموسمين على التوالى . وقد اظهر التحليل الاحصائى لنتائج الموسم الاول نفس اتجاه العلاقه بين الحوريات

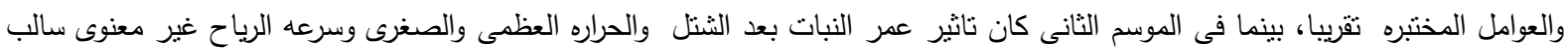
فيما عدا الحراره العظمى كانت معنويه، بينما الرطوبه النسبيه كانت ذات علاقه موجبه غير فير معنويه. سجلت النتائج وجود أربعه قمم عدديه فى الموسم الاول وقمه واحده فى الموسم الثانى لحلم صدأ الطماطم ـ وقد بين التحليليل الاحصائى وجود علاقه موجبه غير معنويه بين أعداد الحلم وجميع العوامل المختبره بموسمى الزراعه، فيماعدا تاثير سرعه الرياح سجلت علاقه

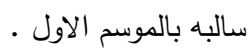

تميز وجود العنكبوت الاحمر على النباتات بوجود ثلاث وخمس قمم لأعداده على النبات فى الموسمين على التوالى ـ وقد اظهرت

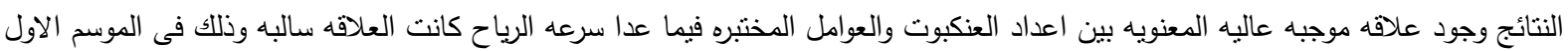
•بينما أظهرت النتائج فى الموسم الثانى وجود علاقه موجبه عاليه المعنويه بين أعداد العنكبوت الاحمر وعمر النبات بعد الثنل وعلاقه معنويه

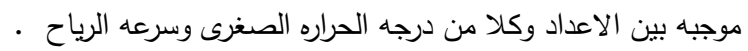

